\title{
Divided we fall
}

\author{
The poor pay the price of increased social inequality with their health
}

In Britain, as in many other countries, the scale of the excess mortality associated with lower social status dwarfs almost every other health problem. The Whitehall study has shown that the most junior office staff have three times the all cause mortality and six times the sickness absence rates of the most senior staff working in the same government offices. ${ }^{12}$ In this week's journal Phillimore and colleagues report that mortality in those aged $0-64$ years is four times higher in the poorest than in the most affluent electoral wards of the Northern region of England. As an indicator of the effect of socioeconomic factors on the demand for services, over three quarters of the regional variation in the number of prescriptions provided per head of population is associated with differences in regional levels of unemployment. ${ }^{3}$

If risks as great as these resulted from exposure to toxic materials then offices would be closed down and populations evacuated from contaminated areas. The research reported by Phillimore and colleagues suggests that the more deprived sections of the population have paid a heavy price for the official failure to take the social causes of disease seriously. Although the apparent widening in mortality differentials between social classes before the 1980 s was treated with some scepticism, particularly by those who were unaware of the gradual increase in relative poverty since the early $1950 \mathrm{~s},{ }^{4}$ few will be surprised by the finding of widening mortality differences between richer and poorer electoral wards in the Northern region during the 1980 s.

The 1980 s were marked by an unprecedented widening of income differences and a growth of relative poverty in Britain, as in several other developed countries. Official figures of incomes after taxes and benefits, adjusted for household size, show that at the start of the decade the incomes of the richest $20 \%$ of the population were four times as large as those of the poorest $20 \%$. By 1991 they were almost six times as large. ${ }^{5}$ That the late 1980s saw not only the most rapid part of this unprecedented widening of income differences, but a simultaneous cessation in the long term fall in national mortality rates among men and women aged 15-44, begs questions about the relation between the two.

The suggestion that the halt in the fall in mortality could have reflected hidden AIDS related mortality is implausible given the simultaneous slowing of the fall in mortality among infants and children. The Phillimore paper casts important new light on the processes underlying these national trends. Widening material differences during the decade were accompanied by widening differences in mortality and by a substantial rise in mortality among men aged 15-44 in the poorer electoral wards. Similar evidence has come from Glasgow. As the most deprived area of Scotland, its previously stable mortality disadvantage increased during the years in which income differentials increased throughout Britain. ${ }^{6}$ Mortality differentials also widened within Glasgow. The report from the British Regional Heart Study of a doubling of mortality rates associated with job loss is no doubt part of this picture (p 1135).

The implication is that increased relative deprivation exerts a powerful influence on national mortality trends. That this is so is confirmed by the international cross sectional association between income distribution and national mortality. It also explains why life expectancy has increased fastest in those developed nations where income differences have narrowed..$^{9}$

\section{On the slide}

Growing socioeconomic divisions are likely to be an important part of the reason why average life expectancy in Britain slipped from 12 th to 17 th position among the 24 nations belonging to the Organisation to Economic Cooperation and Development between 1970 and 1990. As Power describes, several other governments have started to put together policies designed to tackle the effects of disadvantage on health ( $p$ 1153). ${ }^{10}$ If the British government is serious about its health targets it must do so too.

Once it seemed possible that health was best served by faster economic growth, which was incompatible with greater equity. Among the rich nations, however, little or no relation exists between growth and the rate of fall in mortality: the problem is relative not absolute deprivation. Indeed, there is evidence to suggest that national infant mortality rises if the rich get richer while the real incomes of the poor remain constant. "In addition, economists are now changing their minds about the supposed trade off between growth and equity. All eight of the high performing Asian economies reduced their income differences during the period 1960-80, and there is an increasing belief that narrower income differences and increased investment in human capital now play an important role in facilitating modern economic growth. ${ }^{12-14}$ Rather than Britain's poor health performance being a reflection of its poor economic performance, it seems that both have common roots in the social divisions and 
wastage of human skills and abilities among a substantial proportion of the population.

Policies intended to divorce health from deprivation have proved largely ineffective. Reducing the burden of excess mortality attributable to relative deprivation depends on reducing social and economic inequalities themselves. At a recent conference on social variations in coronary heart disease, emeritus professor Jerry Morris made an impassioned plea for a royal commission on policy related to social divisions and national prosperity.

The deep divisions in our society are both a reflection and a cause of financial and human waste on a scale we cannot afford. Their effects reach far beyond health into all areas of human functioning, from economic performance to the quality of life. It is not just a matter of recognising that society exists or of expressing the vain hope of making it classless. It is a matter of discovering how to achieve a more harmonious integration of social and economic forces capable of ensuring our future prosperity and wellbeing. Morris argued that a royal commission was needed because so many government departments have a role. This is an urgent, complicated, and technical issue, and it is one in which many countries are making much better progress than Britain. The pressures to defend political records or gain party advantage are not conducive to the kind of thinking that is needed.

RICHARD G WILKINSON Senior research fellow

Trafford Centre for Medical Research,

University of Sussex,

Brighton BN1 9RY

1 Davey Smith G, Shipley MJ, Rose G. Magnitude and causes of socioeconomic differentials in mortality: further evidence from the Whitehall Study. If Epidemiol Community Health 1990;44:265-70.

2 North F, Syme SL, Feeney A, Head J, Shipley MJ, Marmor MG. Explaining socioeconomic differences in sickness absence: the Whitehall II study. BMF 1993;306:361-6.

3 Office of Health Economics. Compendium of health statistics. London: OHE, 1992.

4 Piachaud D. Poverty in Britain 1899 to 1983. Journal of Social Policy 1988;17:335-49.

5 Central Statistical Office. Economic trends. London: HMSO, 1993;129:475.

6 Greater Glasgow Health Board. The annual report of the director of public health 1991/2. Glasgow: the Board, 1993.

7 Morris JK, Cook DG, Shaper AG. Loss of employment and mortality. BMf 1994;308:1135-9.

8 Wilkinson RG. Income distribution and life expectancy. BMf 1992;304:165-8.

9 Wilkinson RG. Health, redistribution and growth. In: Miliband D, Glyn A, eds. Paying for inequality: the economic costs of social injustice. London: Rivers Oram Press, 1994.

10 Power $C$. Health and social inequality in Europe. $B M f$ 1994;308:1153-6.

11 Waldmann RJ. Income distribution and infant mortality. Quarterly fournal of Economics 1992;107:1283-302.

12 World Bank. World Development Report 1993. Oxford: Oxford University Press, 1993.

13 Birdsall N, Ross D, Sabot R. Inequality and growth reconsidered [presentation]. Boston: American Economic Association, 1994 .

14 Alesina A, Perotti R. Income distribution, political instability, and investment. Cambridge, MA National Bureau of Economic Research, 1993. (Working Paper 4486.)

\section{What happens to the children of single parent families?}

\section{Limited research suggests that socioeconomic circumstances are important}

The wellbeing of children growing up in single parent families has long attracted concern. There are fears that they may fare less well physically, psychologically, economically, and socially than children from intact, two parent families. Some of these children from lone parent families will have parents who have separated or divorced. Others will have suffered the death of a parent. Some may well have only ever lived with one parent.

Children living with their single, never married mothers have become the focus of recent anxiety, perhaps because this group of mothers has been the fastest growing group of lone parents. ${ }^{1}$ At the most recent count (1991) a third of lone parents, caring for more than two million children, were single, never married mothers. Some of these mothers, however, may at some time have lived with the fathers of their children.

Some early research looked at children born "illegitimate," but until recently research concentrated on children whose parents had separated or divorced-probably because of anxiety about the increasing divorce rate in the 1960s. But we know little of the children of today's single, never married mothers, who have been in the eye of the recent political storm.

The Family Policy Studies Centre has recently published a review of mainly British research on the outcomes for children who have either experienced family disruption or lived with a lone parent, or both. ${ }^{2}$ It looks at how these children fared on a range of social, economic, and psychological measures compared with children who live with both their natural parents. These measures include their health at birth, physical development, psychological reaction to the separation of their parents, and educational achievements.

Several methodological "health warnings" are in order before interpreting the results of these studies. Doubts may arise, for example, over the applicability to todays children of these studies of children born in the 1940s and 1950s when illegitimate children would have been something of a rarity. Nor can causation be assured-for example, children's disruptive behaviour could both contribute to and result from family disruption. Causal relations are even harder to establish for outcomes measured in adulthood, such as occupational status. Finally, the results are averages for groups of children and are not applicable to individual children.

Early studies found that, while children born illegitimately lived initially with their mother alone, most were in families with two parents by the age of 7 and a quarter were living with both their natural parents. In general, the research findings suggested that their average health prospects were lower at birth. Researchers who used data from the 1958 British mortality survey found that overall mortality was higher among babies born illegitimate in this cohort and that a higher proportion had a low birth weight $(<2500 \mathrm{~g})$. These differences remained even after birth weight, the birth position of the babies, social class, and the age and smoking habits of the mother were controlled for. ${ }^{3}$ The mothers of illegitimate babies were less likely to have received antenatal care. But illegitimate babies reached developmental milestones at much the same time as legitimate controls and had no greater incidence of physical defects.

Measures of psychological development and behaviour suggest that illegitimate children are more likely to be maladjusted and less academically successful than those in two parent families. But among the illegitimate group better results have been achieved on some measures by children who remained living with their mother alone than by those who subsequently lived with both their natural parents.

The nature of the family disruption may be more important than either the disruption itself or the type of family structure that results. For example, children who live with lone parents who have been widowed often do as well as their peers 